\title{
IODP Expedition 330: Drilling the Louisville Seamount Trail in the SW Pacific
}

\author{
by Anthony A.P. Koppers, Toshitsugu Yamazaki, Jörg Geldmacher, and \\ the IODP Expedition 330 Scientific Party
}

\begin{abstract}
Deep-Earth convection can be understood by studying hotspot volcanoes that form where mantle plumes rise up and intersect the lithosphere, the Earth's rigid outer layer. Hotspots characteristically leave age-progressive trails of volcanoes and seamounts on top of oceanic lithosphere, which in turn allow us to decipher the motion of these plates relative to "fixed" deep-mantle plumes, and their (isotope) geochemistry provides insights into the long-term evolution of mantle source regions. However, it is strongly suggested that the Hawaiian mantle plume moved $\sim 15^{\circ}$ south between 80 and 50 million years ago. This raises a fundamental question about other hotspot systems in the Pacific, whether or not their mantle plumes experienced a similar amount and direction of motion. Integrated Ocean Drilling Program (IODP) Expedition 330 to the Louisville Seamounts showed that the Louisville hotspot in the South Pacific behaved in a
\end{abstract} different manner, as its mantle plume remained more or less fixed around $48^{\circ} \mathrm{S}$ latitude during that same time period. Our findings demonstrate that the Pacific hotspots move independently and that their trajectories may be controlled by differences in subduction zone geometry. Additionally, shipboard geochemistry data shows that, in contrast to Hawaiian volcanoes, the construction of the Louisville Seamounts doesn't involve a shield-building phase dominated by tholeiitic lavas, and trace elements confirm the rather homogenous nature of the Louisville mantle source. Both observations set Louisville apart from the Hawaiian-Emperor seamount trail, whereby the latter has been erupting abundant tholeiites (characteristically up to $95 \%$ in volume) and which exhibit a large variability in (isotope) geochemistry and their mantle source components.

\section{Introduction and Objectives}

Linear trails of volcanic islands and seamounts are a striking and abundant feature in the Pacific Ocean basin. They are believed to form as oceanic crust moves over a relatively stationary magma source or hotspot, which in turn may be caused by a narrow zone of mantle upwelling that results in the partial melting of the ascending mantle

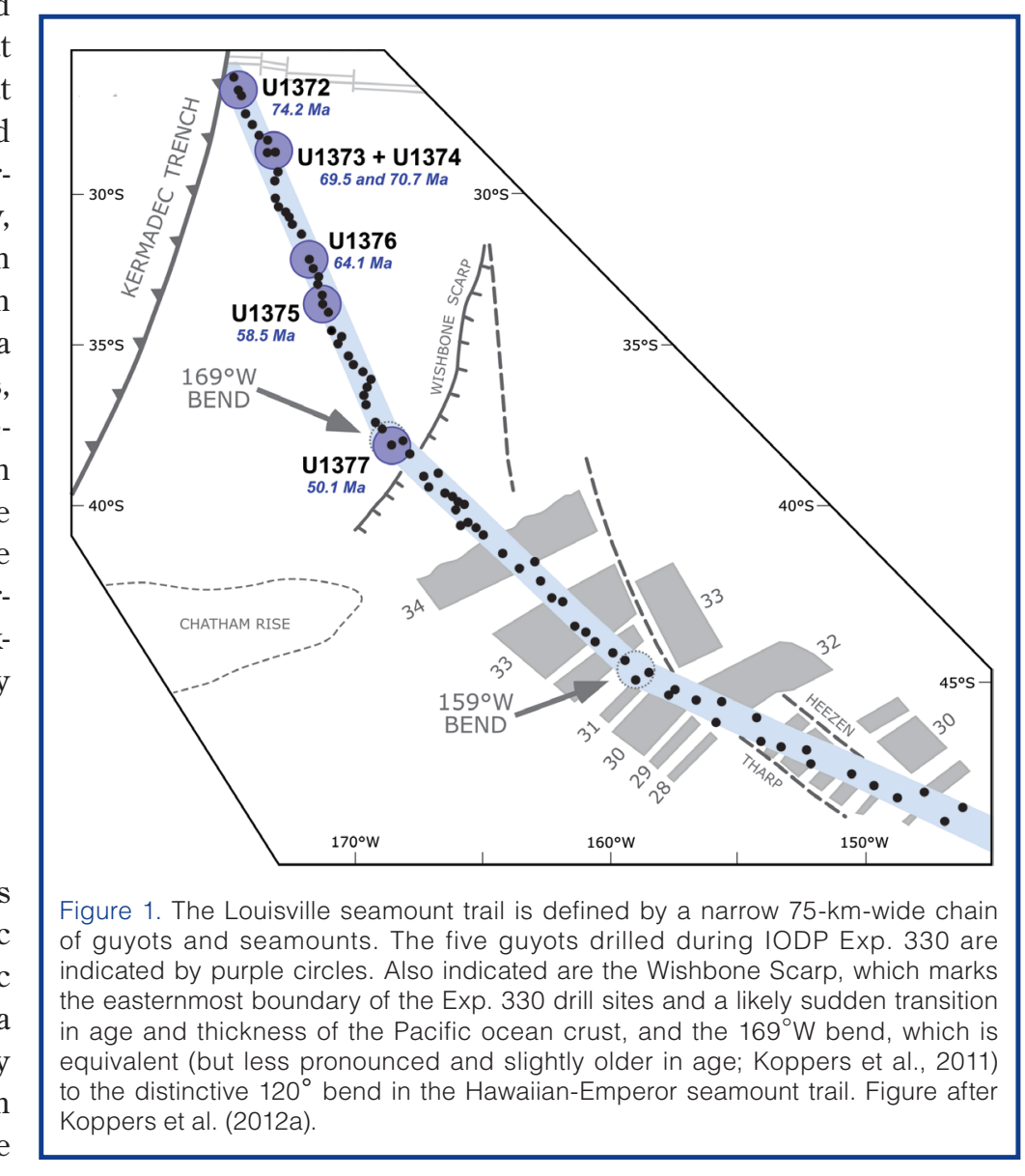

plume material (Morgan, 1971; Wilson, 1963). Consequently, the individual volcanoes in these trails grow older in the direction of plate motion. The 6000-km-long Hawaiian-Emperor seamount trail represents the most famous example, and it is used in many textbooks to explain the hotspot model. Because of its linear morphology, its lack of interfering seamount trails, and its long-lived age-progressive volcanism, the Louisville seamount trail (Fig. 1) is the South Pacific counterpart of the much better studied Hawaiian-Emperor seamount trail (Koppers et al., 2004; Lonsdale, 1988). Both the Hawaiian and Louisville hotspots are considered primary hotspots because of characteristics indicating a deep mantle origin (Courtillot et al., 2003), and since they are located on the same plate, the spatial and age patterns of their volcanoes and seamounts should match the same plate motion parameters (Duncan and Clague, 1985; Koppers et al., 2001; Wessel and Kroenke, 2008; Wessel et al., 2006), assuming that these hotspots remained fixed in the mantle. For example, the distinctive $~ 47-M y r-o l d$ 
bend observed in the Hawaiian-Emperor seamount trail is generally thought to reflect a drastic change in the direction of Pacific plate motion at this time. However, drilling in the Emperor seamounts during Deep Sea Drilling Project Leg 55 and Ocean Drilling Program (ODP) Legs 145 and 197 documented a $\sim 15^{\circ}$ southward shift of the Hawaiian hotspot (relative to the geomagnetic field) between $80 \mathrm{Ma}$ and 50 Ma (Kono, 1980; Tarduno, 2007; Tarduno and Cottrell, 1997; Tarduno et al., 2003, 2009). This large amount of plume motion alone could explain the $120^{\circ}$ bend in the Hawaiian-Emperor seamount trail. In addition, numerical models of mantle-convection confirm that plume conduits may become tilted in response to large-scale horizontal mantle flow, in turn resulting in an absolute motion of hotspots along the Earth's surface (Steinberger and O'Connell, 1998). These models reproduce the observed latitudinal motion of the Hawaiian hotspot but predict essentially no latitudinal but rather a west-to-east longitudinal shift for Louisville models (Steinberger and Antretter, 2006; Steinberger and Calderwood, 2006; Steinberger et al., 2004).

IODP Exp. 330 to the Louisville seamount trail was designed to determine how much the Louisville hotspot moved (if at all) during the $80 \mathrm{Ma}$ to $50 \mathrm{Ma}$ time interval, and if it required a significant plume motion, to determine whether it moved independently from Hawaii (as predicted from the mantle flow models) or in concert (Koppers et al., 2010). To test these end-member geodynamic models was the primary goal of Exp. 330. This required detailed measurements of paleomagnetic inclination onboard the D/V JOIDES Resolution to determine the paleolatitude of the Louisville hotspot at the time of seamount formation, but also the sampling of unaltered basalt flows for onshore ${ }^{40} \mathrm{Ar} /{ }^{39} \mathrm{Ar}$ geochronology to establish the time frame for potential changes in the Louisville hotspot paleolatitude.

Other objectives of Exp. 330 centered around why existing geochemical data from dredged lavas (Beier et al., 2011; Cheng et al., 1987; Hawkins et al., 1987) indicate that the mantle plume source of the Louisville hotspot has been remarkably homogeneous for as long as $80 \mathrm{Myr}$, and why those lavas are predominantly alkali basalts. So far, no evidence has been found that show Louisville seamounts follow a geochemical evolution, such as that observed at the Hawaiian Islands, which comprises a voluminous, tholeiitic shield stage followed by an alkali basalt post-shield or rejuvenated stage. Shipboard geochemistry and planned onshore isotopic analyses of recovered lava flows (and melt inclusions) will provide important insights into the following: (1) origin and magmatic evolution of the Louisville volcanoes and hotspot source, (2) possible plume-lithosphere interaction, and (3) validity of the old hypothesis that the Ontong Java Plateau formed from the initial activity of the Louisville mantle plume around $120 \mathrm{Ma}$.

Finally, during Exp. 330 we also sampled a wide range of lithologies for geomicrobiological studies. Microbiologists accompanying earlier ODP and IODP expeditions documented the presence of microbial life in deeply buried sediments and basaltic basement, but most work to date concentrated on sediments or ocean crust younger than $3.5 \mathrm{Ma}$ (Cowen et al., 2003; Mason et al., 2010). Stable isotope evidence (Rouxel et al., 2008) and microbial fossils (Fisk, et al., 1998; Parkes et al., 1994) indicate that there is a subsurface biosphere in older volcanic basement rocks as well. Exp. 330 provided an excellent opportunity to study living and extant microbial resi-dents within 80-50 Myr old seamount basalt flows as well as volcaniclastics that make up the Louisville seamounts. In total, more than sixty microbiology samples were collected from four seamounts up to a maximum depth of 516 meters below seafloor (mbsf).

\section{Geologic Setting}

The 4300-km-long Louisville seamount trail (Fig. 1) is a linear age-progressive chain of at least sixty-five major volcanic seamounts (Koppers et al., 2011; Lonsdale, 1988) and is considered a classical example of a hotspot track. The seamounts of the Louisville seamount trail range in age from $\sim 80 \mathrm{Ma}$ at its northwestern end (Koppers et al., 2004) to pro-

Table 1. IODP Exp. 330 drilling statistics and paleomagnetic sampling of basalts.

\begin{tabular}{|c|c|c|c|c|c|c|c|c|c|c|}
\hline \multicolumn{5}{|c|}{ IODP Expedition 330} & \multicolumn{5}{|c|}{ In Situ Confidence Index (ISCI) } & \multirow{3}{*}{$\begin{array}{c}\text { Total Number } \\
\text { Discrete } \\
\text { Samples }\end{array}$} \\
\hline \multirow{2}{*}{$\begin{array}{l}\text { Drill } \\
\text { Site }\end{array}$} & \multirow{2}{*}{$\begin{array}{l}\text { Seamount } \\
\text { Name }\end{array}$} & \multirow{2}{*}{$\begin{array}{l}\text { Penetration } \\
\text { Depth }(m)\end{array}$} & \multirow{2}{*}{$\begin{array}{l}\text { Basement } \\
\text { Cored (m) }\end{array}$} & \multirow{2}{*}{$\begin{array}{l}\text { Recovery } \\
\text { Rate (\%) }\end{array}$} & 3 & 2 & 1 & 0 & \multirow{2}{*}{$\frac{\text { N/A }}{\text { (volc sed) }}$} & \\
\hline & & & & & \multicolumn{4}{|c|}{ (in situ basalt units) } & & \\
\hline U1372 & $\begin{array}{l}\text { Canopus } \\
\text { Guyot }\end{array}$ & 232.9 & 187.3 & 55.8 & 19/8 (22) & $2 / 1(4)$ & 8 & 2 & 10 & 100 \\
\hline U1373 & Rigil Guyot & 65.7 & 31.8 & 90.6 & $10 / 9(10)$ & $0 / 0(0)$ & -- & -- & 14 & 34 \\
\hline U1374 & Rigil Guyot & 522.0 & 505.3 & 87.8 & $12 / 14(18)$ & $6 / 5(7)$ & 18 & 8 & 47 & 243 \\
\hline U1375 & $\begin{array}{l}\text { Achernar } \\
\text { Guyot }\end{array}$ & 20.0 & -- & -- & -- & -- & -- & -- & -- & -- \\
\hline U1376 & Burton Guyot & 182.8 & 140.9 & 75.6 & $6 / 7(8)$ & 2/1 (3) & 6 & 0 & 10 & 99 \\
\hline \multirow[t]{2}{*}{ U1377 } & Hadar Guyot & 90.3 & 66.1 & 36.5 & $12 / 2(15)$ & $0 / 1(1)$ & 0 & 0 & 2 & 17 \\
\hline & & & & TOTALS & $59 / 40(73)$ & $10 / 8(15)$ & 32 & 10 & 79 & 493 \\
\hline
\end{tabular}

On the left-hand side drilling statistics include depth of penetration, total thickness of igneous basement drilled and core recovery. On the right-hand side sample statistics list number of inclination averages that are available for individual lithological units from 2-cm archive half measurements (first number in bold) and from discrete samples (second number in bold). These numbers are expressed as a function of the In Situ Confidence Index (ISCI) that ranges from ISCI=3 for units that are definitely in situ to ISCI=0 for those that are likely not. Most volcaniclastic units were assigned an ISCI value of "not applicable" as it is unclear whether clasts in these volcanic sediments retained their orientation since eruption and emplacement. For the paleolatitude estimates we use results only from the most reliable units $(\mathrm{ISCl}=3$ or 2$)$ although it is significant that many volcaniclastic units yield inclinations consistent with intercalated in situ flows (cf. Figs. 7 and 8). Table from Koppers et al. (2012b). 
bably recent times at its southeastern end. The exact location of the present-day hotspot is difficult to determine; it lies somewhere near the Eltanin Fracture Zone and the SW Pacific-Antarctic Ridge (Koppers et al., 2011; Watts et al., 1988). At the northern end of the trail, Osbourn Guyot (79 Ma; Koppers et al., 2004) is being subducted into the Tonga-Kermadec trench at $25.8^{\circ} \mathrm{S}$. The oceanic crust beneath the northern part of the trail was formed at Osbourn Trough, a fossil spreading center that was active before $87 \mathrm{Ma}$ or $93 \mathrm{Ma}$ (Downey et al., 2007; Worthington et al., 2006) or 115 Ma (Mortimer et al., 2006), depending on the plate reconstruction models used. At $\sim 38^{\circ} \mathrm{S}$, the Louisville seamount trail crosses the western branch of the Wishbone Scarp that separates older oceanic crust formed at the Osbourn Trough to the west from younger crust created at the Pacific-Antarctic Ridge (Watts et al., 1988). It is expected that the presence of the fracture zone and the associated step in lithosphere thickness influences the mantle melting zone and hence the geochemical compositions of the lavas from Hadar Guyot, the youngest seamount drilled during Exp. 330. Dredged samples from Louisville seamounts located between the two branches of the Wishbone Scarp confirm this view by being more variable in composition compared to the general quite uniform geochemical composition of the Louisville seamounts (Beier et al., 2011).

\section{Summary of Drilling Results}

Exp. 330 replicated as closely as possible the drilling strategy of ODP Leg 197, which provided compelling evidence for mantle plume motion of the Hawaiian hotspot between $\sim 80 \mathrm{Ma}$ and $50 \mathrm{Ma}$. The seamounts drilled in the Louisville seamount trail were of similar ages with respect to Detroit, Suiko, Nintoku, and Koko seamounts in the Hawaiian-Emperor seamount trail. In total, six sites were drilled during Exp. 330 along the old end of the Louisville seamount trail on the summit plains of Canopus (U1372), Rigil (U1373, U1374), Burton (U1367), Achernar (U1375), and Hadar (U1377) Guyots. In two cases larger seamount structures were targeted and drilled near their flanks; in the other three cases smaller edifices were drilled closer to their centers. Drilling and logging plans for each of these sites were similar, with coring reaching maximum depth of 522.0 mbsf for Site U1374 and 232.9, 65.7, 11.5, 182.8 and 53.3 mbsf for Sites U1372, U1373, U1375, U1376 and U1377, respectively (Table 1 ). The pelagic ooze cover was cored using a gravity-push approach with little or no rotation of the rotary core barrel assembly to maximize recovery; when no pelagic ooze was present, the holes were started directly into (often) cobble-rich hardgrounds. Volcanic basement was reached at four of the drilling targets, and downhole logging was successfully carried out for Sites U1374 and U1376. 
From top to bottom the drilled sequences are generally characterized by (i) an absent or thin ( $<13.5$-m-thick) layer of recent pelagic ooze; (ii) an older seamount sedimentary cover (0.3-41.9 m thick) of volcanic breccias, conglomerates and sandstones, and condensed limestones; (iii) an upper volcanic sequence (23.0-99.8 $\mathrm{m}$ thick) dominated by massive lava flows inter-layered with volcaniclastic sediments; and (iv) a lower volcanic sequence (70.2-405.5 m thick) characterized principally by volcaniclastics and hyaloclastites, but interspersed with in situ massive lava flows, smaller lava pods, pillow lavas, and subvertical dike intrusions (Fig. 2). At all sites the older sedimentary cover comprised sequences of volcanic sandstone (Fig. 3a) and various kinds of breccia (Fig. 3c) or conglomerate (Fig. 3d) that in some cases were interlayered with the spatter/tephra pro-
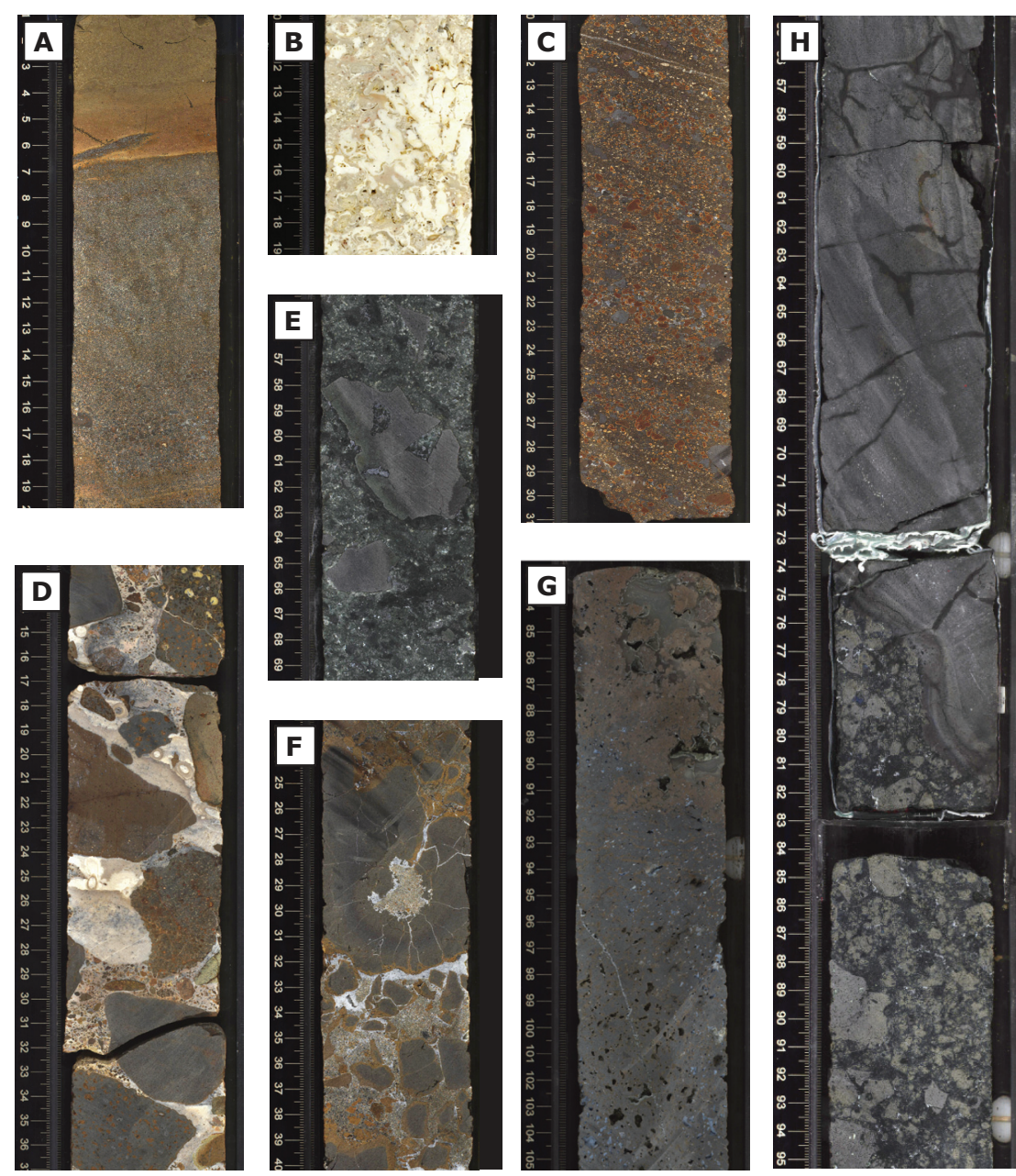

Figure 3. Lithological variation displayed in core images. [A] Monolithic bioturbated brown coarse tuff (top) and heterolithic multicolor volcanic sandstone (bottom) from Site U1376 (interval 330-U1376A-3R-4, 1-41 cm) deposited as turbidites in a hemipelagic or pelagic environment. [B] Algal boundstone with a branching growth form of algae from Site U1376 (interval 330-U1376A-3R-5, 10-29 cm) interpreted as a reef. [C] Multicolor coarse (layered) volcanic sandstone/breccia at Site U1374 (interval 330-U1374A-8R-1, 10-50 cm) interpreted to have been emplaced on a shallow-marine slope as a hyperconcentrated flow. [D] Multicolor basalt conglomerate emplaced under hemipelagic conditions at Site U1375 (interval 330-U1375A-2R-1, 1-41 cm) with inter-pebble spaces composed of foraminiferal limestone, finer-grained volcaniclastic sediment and carbonate cement. [E] Angular aphyric basalt clasts in hyaloclastite matrix at Site U1374 (interval 330-U1374A-66R-6, 55-69 cm). [F] Example of magma-sediment (peperitic) interaction observed at Site U1374 (interval 330-U1374A-17R-3, 20-40 cm). [G] Flow top at the upper (peperitic) boundary of a massive ( 23-m-thick) aphyric basalt flow at Site U1373 (interval 330-U1373A-9R-2, 83-105 cm). $[\mathrm{H}]$ Aphyric subvertical dike intrusion (top) into hyaloclastite breccia sequence (bottom) at Site U1376 (interval 330-U1376A-15R-2A, 22-95 cm). Figure after Koppers et al. (2012a). ducts of submarine eruptions (Fig. 3f) or (autobrecciated) basaltic lava flows with peperite flow tops (Fig. 3g). In this cover several (thin) intervals of carbonate were cored, with occurrence of a 15 -m-thick algal limestone reef (Fig. 3b) on Burton Guyot. At Sites U1372 thror were comprised of a high fraction of volcaniclastics (Figs. 3e, interspersed by in situ lava flows and a few dike intrusirine (deeper in the sequences) to subaeral ments at the top of the volcanic basement (Fig. 5). However, at Sites U1376 and U1377 the igneous basements comprised submarine volcanic sequences only.

The average coring recovery rate was high at $72.4 \%$, and in the case of Site U1374 on Rigil Guyot, a total of 522 meters was drilled at a record-breaking 87.8\% (Table 1; Expedition 330 Scientists, 2011). The high recovery rates provide a high level of confidence in our understanding of the volcanic history at each drill site and seamount. Although the flat guyot tops indicate that these Louisville volcanoes formerly had subaerial summits, there is no evidence for extensive subaerial eruptions, and most recovered material represents (shallow) submarine volcanism during the main constructional phase of each volcano. The ${ }^{40} \mathrm{Ar} /{ }^{39} \mathrm{Ar}$ age dating, paleomagnetic measurements, and (isotope) geochemistry studies are focusing primarily on the in situ lava flows, pillow units, and subvertical dike intrusions from this submarine constructional phase, all of which will allow direct comparison of the paleolatitude estimates and geochemical signatures of the two longest-lived hotspot systems in the Pacific Ocean.

\section{Site U1372 on Canopus Guyot}

At Hole U1372A 46 meters of sedimentary deposits and 187 meters of igneous basement were drilled (Fig. 2). The hole was abandoned at $232.9 \mathrm{mbsf}$, and no downhole logging was carried out, because the drill string became irretrievably stuck in rubbly volcaniclastic breccia. The sedimentary units consist of 14 meters of unconsolidated sandy foraminiferal ooze of late Miocene or younger in age, overlying $\sim 32$ meters of basaltic breccia and conglomerate with a minor interval of foraminiferal limestone of Cretaceous to early Paleogene age, which is interpreted to have been formed under neritic to hemipelagic water conditions. 
The igneous basement section of the hole can be divided broadly into an upper (83-m-thick) part consisting of lava flows and a lower (104-m-thick) part composed mostly of volcaniclastics. The lava flows likely erupted subaerially or in very shallow marine conditions, because peperitic or scoriaceous, oxidized flow tops were observed. The igneous rocks typically have phenocryst assemblages of olivine only, olivine + plagioclase (+ augite) (Fig. 4a) or plagioclase + augite. Pyroxene phenocrysts and microphenocrysts are always titaniferous. Olivine is present in the groundmass in several of the upper series of lava flows but not in those from the lower part of the succession, implying an increase in alkalinity upward through the basement section. The presence of titanaugite indicates that these rocks are not

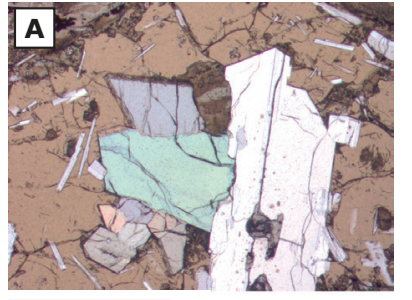

$1 \mathrm{~mm}$

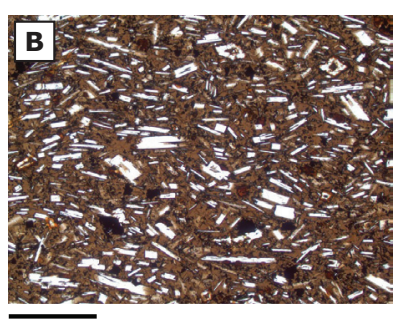
$1 \mathrm{~mm}$

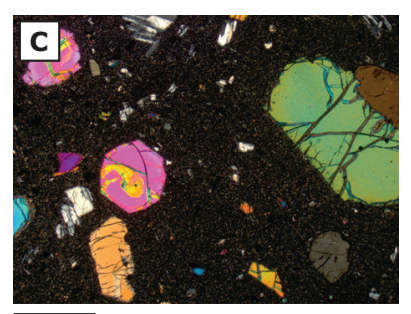

$\overline{1 \mathrm{~mm}}$

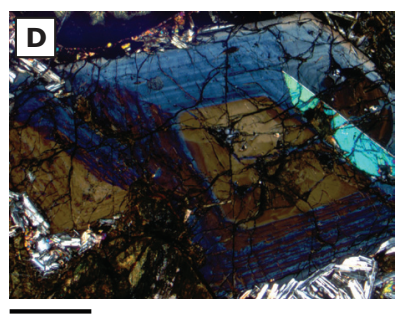

$1 \mathrm{~mm}$

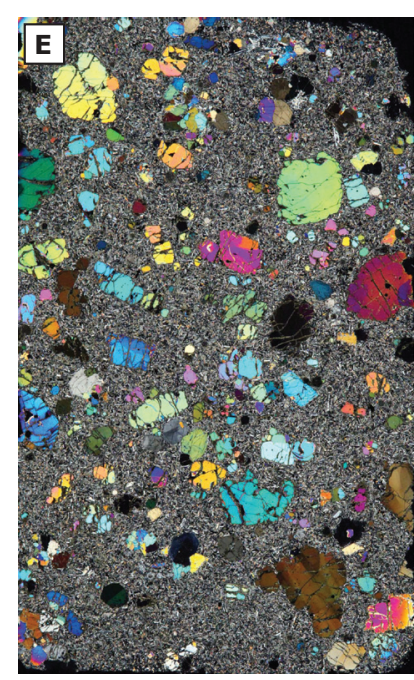

$10 \mathrm{~mm}$

Figure 4. Petrographic variation in alkali basalt lava flows displayed in photomicrographs. [A] Olivine and plagioclase phenocrysts in a glass matrix with smaller plagioclase microcrysts at Site U1372 (sample 330-U1372A-18R-3, 14-16 cm; cross-polarized light). [B] Aphyric basalt showing glassy groundmass, small unaltered groundmass olivine, and flow-aligned plagioclase laths at Site U1374 (sample 330-U1374A-19R-1, 50-53 cm; plane-polarized light). [C] Highly olivine-titanaugite-plagioclase-phyric basalt from a clast in a conglomerate of the sediment cover at Site U1373 (sample 330-U1373A-1R-2, 123-125 cm; cross-polarized light). [D] Ti-augite phenocryst in highly olivine-augite-phyric basalt at Site U1373 (sample 330-U1373A-7R-1, 84-86 cm; cross-polarized light). [E] Highly olivine-augite-phyric basalt at Site U1376 (sample 330-U1376A-8R-6, 136-140cm; cross-polarized light). Figure after Koppers et al. (2012a).

tholeiitic. Geopetal structures in

the upper part of the sequence are all horizontal, indicating that the drilled succession has not been tilted since its formation. Similar horizontal geopetal structures were observed also at all succeeding sites drilled during Exp. 330.

The entire igneous section has undergone various degrees of secondary alteration by low-temperature water-rock interaction and weathering. Down to $90 \mathrm{mbsf}$ the volcanic basement has a dominantly reddish alteration color, indicating an oxidizing environment under likely subaerial or shallow submarine conditions, but below $\sim 90 \mathrm{mbsf}$ the alteration becomes more greenish, pointing toward more reducing conditions related to a deeper submarine environment (Fig. 5). Typically, these basaltic lava flow units are fresher than volcaniclastic units and are only moderately altered. Relatively unaltered olivine phenocrysts were found throughout all basement units, as were zones with fresh volcanic glass, particularly in hyaloclastites (Fig. 4a). Shipboard major and trace element data indicate that the majority of the igneous rocks are alkali basalt, but several are transitional (Fig. 6a). Using shipboard geochemistry alone, no distinction between shield and post-shield stages of volcanism can be made (Fig. 6b).

The natural remanent magnetization (NRM) was measured on archive halves at 2-cm intervals (Fig. 7) as well as on discrete samples. Most of the lava flows and a few volcaniclastic sequences also have relatively high magnetic coercivities, whereas drilling-induced magnetic overprinting was negligible. In intervals that can be most confidently identified as in situ lava flows, inclinations are generally steep and negative (normal polarity). The flow-unit mean

inclination determined shipboard from discrete samples on nine in situ flow units (Fig. 8a) is $-61.7^{\circ} \pm 7.2^{\circ} / 8.8^{\circ}(2 \sigma)$ after applying bootstrapping techniques and inclination-only statistics (Koppers et al., 2012a).

\section{Sites U1373 and U1374 on Rigil Guyot}

\section{Site U1373}

At Hole U1373A $~ 31.8$ meters of igneous basement was drilled beneath a $\sim 34$-m-thick sediment cover of consolidated sediments of latest Cretaceous to Miocene age that also includes three intercalated autobrecciated basaltic lava flows (Fig. 2). Because reentry using a free-fall funnel failed, this hole had to be abandoned at $65.7 \mathrm{mbsf}$. The sequence of volcanic and sedimentary rocks recovered is part of the subaerial phase of Rigil Guyot construction. Volcanological features of the igneous sequence suggest lava flowing into an area where water or water-saturated sediment is present but not fully submarine. Above $\sim 45 \mathrm{mbsf}$ the sequence has a dominantly reddish alteration color, pointing toward an oxidizing environment under likely subaerial conditions, but below $\sim 45$ mbsf nearly fresh basalt is faintly greenish, pointing to more reducing conditions related to the submarine environment of lava flow emplacement (Fig. 5).

The igneous basement consists of highly olivinetitanaugite-phyric basalt with well-preserved olivine phenocrysts and aphyric basalt (Fig. 3g). The presence of titanaugite and olivine-titanaugite phenocryst assemblages is characteristic of alkalic basalt (Figs. 4c, 4d). Shipboard chemical analyses showed that igneous samples from Site U1373 
are closely similar in major and trace element composition to basalt from Site U1372 (Fig. 6b). Total alkali $\left(\mathrm{Na}_{2} \mathrm{O}+\mathrm{K}_{2} \mathrm{O}\right)$ and $\mathrm{SiO}_{2}$ concentrations indicate that all Site U1373 samples are alkali basalt, except one sample classified as a transitional basalt (Fig. 6a).

Paleomagnetic measurements showed mostly negative (normal polarity) inclinations, but positive (reversed polarity) inclinations were recorded in the uppermost units, which comprise sediments and volcanic breccia (Figs. 7, 8b). The mean inclination of nine in situ flow units is $-55.2^{\circ} \pm 10.6(2 \sigma)$ as determined from discrete samples using inclination-only statistics (Koppers et al., 2012b).

\section{Site U1374}

The drilled sequence of Hole U1374A constitutes $6.6 \mathrm{~m}$ of Pleistocene-Holocene sandy foraminiferal ooze, a 10.1-m-thick sediment layer of Cretaceous age consisting of consolidated volcanic sandstone, a thin layer of limestone and basalt conglomerate, and $505.3 \mathrm{~m}$ of igneous basement (Fig. 2). The igneous sequence, from the bottom up, starts with submarine volcanism, producing a series of volcanic breccia units with an increasing number of in situ lava lobes and more massive flows upward in the sequence. In the bottom $186 \mathrm{~m}$, the breccia units are frequently interrupted by a series of intrusive sheets or dikes of mainly aphyric basalt. The sequence above $\sim 291 \mathrm{mbsf}$ is occasionally interrupted by sedimentary intervals. Magmatism progressed to a shallow-marine and

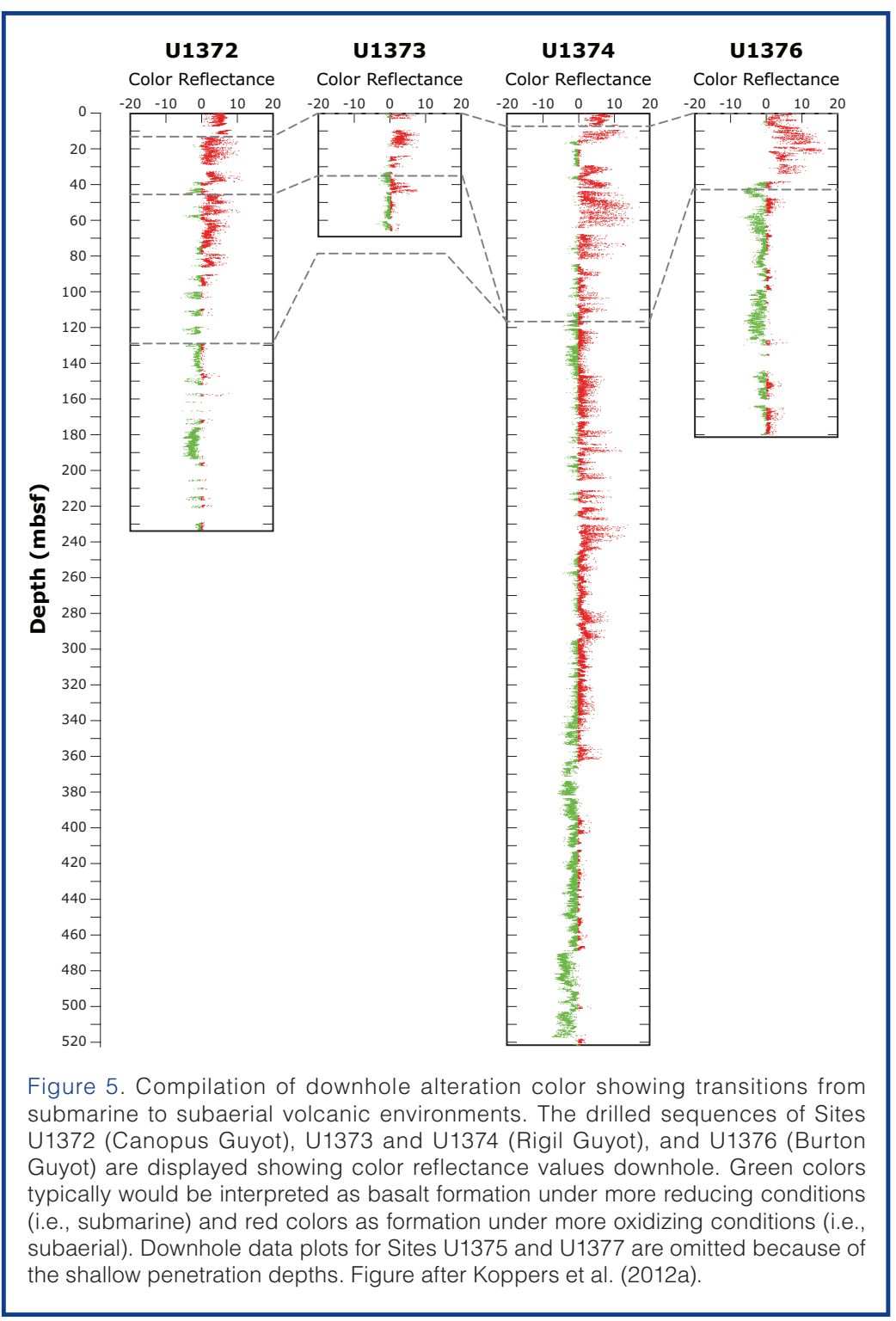
then subaerial environment. This progression is particularly evident in the various breccia types (Figs. 3c, $3 e, 3 f)$ recovered at this site that range from green hyaloclastite breccia with frothy basaltic clasts (marine) through blocky breccia (shallower marine) to scoriaceous (near sea level or subaerial). Changes in alter-ation color are consistent with this progression (Fig. 5).

The phenocryst assemblage in the breccia and lava flows changed from plagioclase-dominated in the lower part of the succession to olivine-dominated in the upper part, suggesting that the magmas became generally more alkaline with time (Fig. 4b). Major and trace element data for igneous samples from Site U1374 overlap considerably with data for Sites U1372 and U1373, but are slightly more alkalic as a group (Fig. 6b). Most Site U1374 samples are classified as alkali basalt, but nearly one-third of the samples are basanite or tephrite (Fig. 6a). No transitional compositions were found. Despite the compositional overlap and close proximity of Sites U1373 and U1374, the rocks from the two sites cannot be correlated, and they probably represent distinct eruptive events. Likewise, the intrusive sheets at Site U1374

cannot be correlated with any specific lava flow or eruption package higher up in the drilled sequence.

The entire lower sequence has a normal magnetic polarity, which above $45 \mathrm{mbsf}$ is overlain by a package of reversely magnetized lava flows and volcaniclastics (Figs. 7, 8c). The mean inclination of the nineteen in situ flow units determined from discrete samples is $-68.7^{\circ} \pm 8.4^{\circ}(2 \sigma)$ after correction for deviation of the borehole from vertical and using inclination-only statistics (Koppers et al., 2012b). It is notable that volcaniclastic units, especially in the lower half of the cored igneous basement, provided inclination values similar to intercalated lava flows or lobes. In addition, many of the intrusive sheets intruding these volcaniclastic units also have comparable negative inclinations. The most reliable inclination estimate for Rigil Guyot can be obtained by combining these results with the nine in situ lava flows recovered at Site U1373, which are younger by only $~ 1$ Myr (Koppers et al., 2012b). This results in a combined bootstrap mean inclination of $-65.0^{\circ} \pm 4.6^{\circ} / 7.3^{\circ}(2 \sigma)$ using inclination-only averaging that is within error (on $1 \sigma$ and $2 \sigma$ uncertainty levels) of 
the geocentric axial dipole inclination $\left( \pm 68^{\circ}\right)$ for the presentday Louisville hotspot location at $\sim 51^{\circ} \mathrm{S}$ (Koppers et al., 2012b).

\section{Site U1375 on Archernar Guyot}

Hole U1375A was drilled to only 11.5 mbsf. Latest Miocene and younger foraminiferal ooze were recovered, underlain by Paleocene basalt conglomerate (Fig. 3d) and breccia, which represent a pelagic cap and the older sedimentary cover of Achernar Guyot. Hole U1375B was drilled to $8.5 \mathrm{mbsf}$, and it recovered $57 \mathrm{~cm}$ of igneous rock only, which likely is from a large boulder in the sediment cover. Severe hole instabilities were encountered at both holes, and this site had to be abandoned.
The igneous rock from Hole U1375B is composed of moderately olivine-augite-phyric microgabbro (dolerite) with olivine and augite phenocrysts larger than $10 \mathrm{~mm}$. This unit is moderately altered and highly evolved (Fig. 6b). It represents one of the most alkalic rocks recovered during Exp. 330 as it lies in the field of basanite and tephrite in a classification diagram of total alkali $\left(\mathrm{Na}_{2} \mathrm{O}+\mathrm{K}_{2} \mathrm{O}\right.$ vs. $\left.\mathrm{SiO}_{2}\right)$ (Fig. 6a).

\section{Site U1376 on Burton Guyot}

At Hole U1376A a 42-m-thick Cretaceous to Miocene consolidated sediment cover and a $141-\mathrm{m}$-thick igneous basement sequence were drilled (Fig. 2). At the top, the sediment cover comprises mainly volcanic sandstones (Fig. 3a) and breccias that overlie a remarkable $\sim 15$-m-thick white algal limestone (Fig. 3b). At its base, the sedimentary cover is composed of basalt conglom-erate unconformably overlying the igneous basement. Record of a post-erosional or rejuvenation phase of magmatism at this site is provided by the volcanic sand and breccia. Some of the sand layers contain fragments of hornblende and biotite, implying the eruption of magma more evolved than that represented by the more basic basement succession. The sequence contains olivine-pyroxene aggregates that may be mantle xenoliths. This is supported by the occurrence of partly resorbed orthopyroxene xenocrysts in basalt clasts with clear reaction coronas, suggesting that the rejuvenated stage magmas were strongly alkaline.

The igneous basement is composed of a sequence of submarine pillow basalts, hyaloclastites, and autobrecciated lava flows. No subaerial eruptive products were encountered. The dominance of submarine eruption is also indicated by alteration type. Two stratigraphic units were defined for the igneous basement: the lower unit contains mostly olivine phenocrysts, overlain by the upper unit containing olivine and augite phenocrysts. The lower unit is cut by dikes, and it has an erosional surface at its top (Fig. 3h). The presence of olivine and augite phenocrysts in this basalt (Fig. 4e) and the complete absence of plagioclase phenocrysts suggest that the seamount magma was alkaline and more basic than that at Sites U1372, U1373, and U1374. Geochemical analyses show that the basalt at Site U1376 is slightly less alkaline, although it is still classified as transitional basalt rather than tholeiitic (Fig. 6).

Inclination data from paleomagnetic measurements on archive halves and discrete samples provide a remarkably consistent picture of moderate to steep reversed polarity magnetization (Figs. 7, $8 d)$. Very similar inclinations were measured for
Figure 6. Compilation of shipboard geochemistry data. [A] Total alkalis vs. silica of Bas et al. (1986) with division of alkaline vs. subalkaline (tholeiitic) series from Macdonald and Katsura (1964), showing an absence of tholeiitic rocks in the current sample suites for the Louisville seamount trail. [B] $\mathrm{TiO}_{2}$ vs. Sr compared against fields for several Hawaiian volcanoes (in gray-black outlines) distinguishing "Hawaii shield" from "Hawaii post-shield" volcanism. Also shown are fields for the southern East Pacific Rise (EPR) and Ontong Java Plateau (OJP). Dredge sample data include samples with Loss of Ignition (LOI) $<6$ wt\% only (Beier et al., 2011; Hawkins et al., 1987; Vanderkluysen et al., 2007). All major element data are normalized to $100 \mathrm{wt} \%$ totals. Figure after Koppers et al. (2012a). 
volcaniclastic and sedimentary units, as well as for two intrusive dikes, which suggests it is possible to obtain a reliable paleolatitude for this site. The bootstrap mean inclination of eight in situ flow units determined from discrete samples is $-67.1^{\circ} \pm 3.5^{\circ} / 3.5^{\circ}(2 \sigma)$ after correction for deviation of the borehole from vertical (Koppers et al., 2012a).

\section{Site U1377 on Hadar Guyot}

Two holes were drilled at Hadar Guyot, but drilling reached only $53.3 \mathrm{mbsf}$ in Hole U1377A and $37 \mathrm{mbsf}$ in Hole U1377B due to hole instabilities. Both holes started out with nannofossil foraminiferal ooze, followed by an older sedimentary cover including middle-late Eocene pelagic limestone and late Paleocene to early Eocene volcanic breccia and conglomerate.

The igneous basement at Site U1377 consists of trachybasalt, which is a more evolved lithology than the alkali basalt drilled at the other Exp. 330 sites, but similar to lithologies drilled during prior dredging expeditions (Fig. 6). These trachybasalts exhibit intervals of pronounced flow banding, suggesting they formed as massive lava or smaller lobate flows, although lower in Hole U1377B smaller cooling units with well-preserved curved glassy margins were encountered. These margins are diagnostic of lobate flows or pillows and emplacement in a submarine environment. Brown to reddish-brown alteration indicates the prevalence of oxidizing conditions in both holes. Paleomagnetic measurements revealed that samples of three in situ flow units have positive incli-

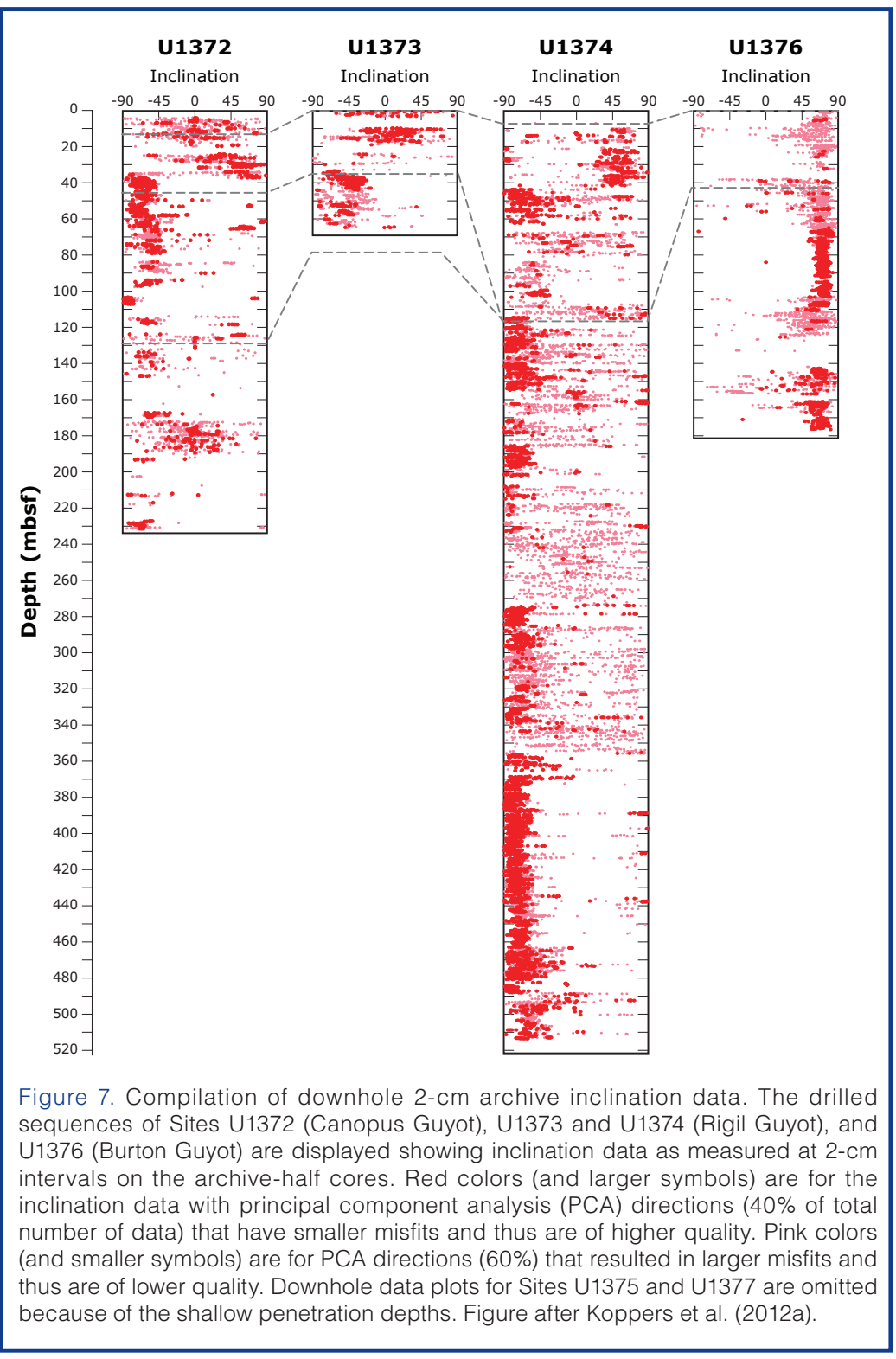
nations (reversed polarity) resulting in a bootstrap mean inclination of $-68.9^{\circ} \pm 14.6^{\circ} / 13.6^{\circ}(2 \sigma)$ (Koppers et al., 2012b).

\section{Discussion}

\section{Limited Louisville Mantle Plume Motion}

In a scenario with all Pacific mantle plumes sustaining similar large motions as the Hawaiian hotspot, mantle convection is likely to sustain only a few global-scale cells and to create a prevailing "mantle wind" in the Pacific that advects mantle plumes into parallel directions with equal speeds. Hotspots still would provide a valuable reference frame against which plate motions can be measured, as this network of mantle plumes would move consistently over geological time. However, in an alternate scenario, with each hotspot experiencing its own amount and a unique direction of mantle plume motion, inter-hotspot motion would be substantial resulting from plume motions that are regionally controlled (for example, by different configurations of

large-scale deep mantle upwellings (such as superplumes) and downwellings (such as subduction zones)). Using shipboard paleomagnetic data, we could show (Koppers et al., 2012b) that the latter scenario is the more likely. Between $70 \mathrm{Ma}$ and $50 \mathrm{Ma}$, the Louisville hotspot paleolatitude varied only $3^{\circ}-5^{\circ}$ north of its present-day $51^{\circ} \mathrm{S}$ latitude. These observations match predictions from whole Earth mantle flow modeling, which amount to a maximum of $2^{\circ}-2.5^{\circ}$ of southward motion (Koppers et al., 2004; Steinberger et al., 2004), even though these models do allow for a significant amount of longitudinal motion that paleomagnetic measurements cannot detect. Nevertheless, the observed limited latitudinal motion for the Louisville hotspot (Koppers et al., 2012b) suggests that the Hawaiian and Louisville mantle plumes have been moving independently and that the motion of the Louisville hotspot is likely governed by the subduction of the Pacific plate in the Tonga-Kermadec subduction zone to the west, causing a pronounced return flow in the mantle toward the east and in the direction of the Pacific-Antarctic mid-ocean ridge. The large difference in mantle plume motions also has consequences for interpreting the morpholo- 
gies of seamount trails. It now becomes more likely that the Hawaiian-Emperor bend is caused by the strong independent motion of the Hawaiian plume (Tarduno, 2007 ) and that the shape and age progression of the Louisville seamount trail is providing a better indication of Pacific plate motion. However, an alternate option (which cannot be disproven with paleomagnetic data) could be that a strong eastward motion of the Louisville plume is masking the true motion of the Pacific plate as those two motion vectors would be anti-parallel in direction.

\section{Louisville Seamounts Construction and the Mantle Source}

The composition of the drilled rock samples overlaps those analyzed from the dredged rocks but covers a smaller range of variation. All dredged and drilled samples from the Louisville seamount trail are alkali and transitional basalts or basanites and tephrites containing normative nepheline (Fig. 6a). Drilling of up to $505 \mathrm{~m}$ into the igneous basement of Rigil Guyot and into the submarine-erupted parts of (in total) four Louisville seamounts did not reveal any tholeiitic basalts and, therefore, did not yield any evidence that Louisville volcanoes evolve through compositionally different stages, such as observed for Hawaii and most intra-plate (hotspot) islands/seamounts. Together with the remarkably homogeneous trace element (Fig. 6b) and isotopic composition of all Louisville lavas, this indicates a homogeneous mantle source that is not significantly affected by variable degrees of melting and/or source fertility (Chen and Frey,

1985; Geldmacher et al., 2006; Phipps Morgan, 1999). Alternatively, only limited variation in lithospheric thickness (along the seamount trail) could be responsible for uniform melting conditions (Beier et al., 2011), but this would not explain the compositional homogeneity observed for each individual seamount (e.g., the lack of tholeiitic shield stages) unless different melting processes (compared to Hawaii) are considered. Further detailed post-cruise studies including $\mathrm{Sr}, \mathrm{Nd}, \mathrm{Pb}$ and $\mathrm{Hf}$ isotope ratios on whole rocks, volcanic glass and melt inclusions are underway to investigate these questions.

Major element and Sc variations in the Exp. 330 lava flows indicate that olivine and clinopyroxene are the main fractionating mineral phases controlling the magmatic differen-
Site $\mathbf{U 1 3 7 2}$
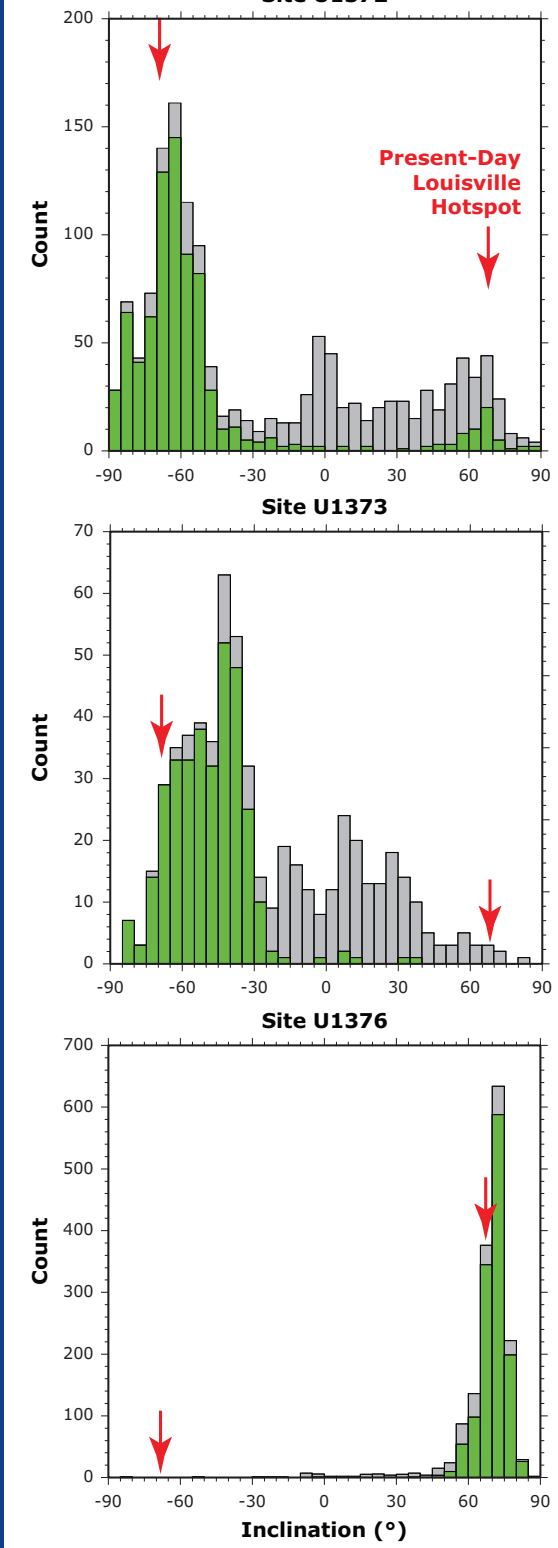

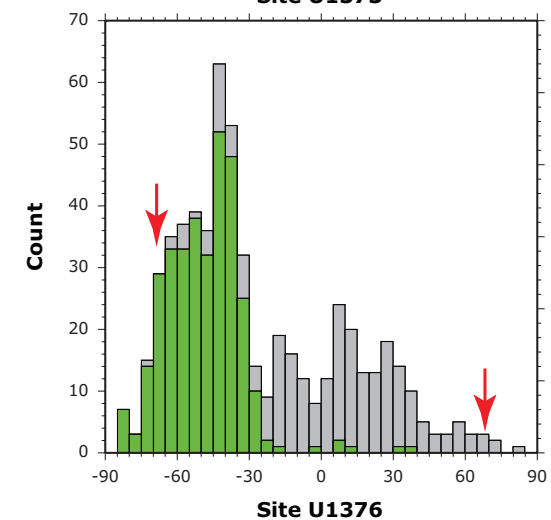

DATA COUNTS

\begin{tabular}{|l|c|c|c|c|c|}
\hline & U1372 & U1373 & U1374 & U1376 & U1377 \\
\hline ALL DATA & 1364 & 576 & 5496 & 1580 & 219 \\
\hline LAVA FLOWS & 776 & 333 & 1065 & 1329 & 208 \\
\hline \\
$\begin{array}{l}\square \text { All 2-cm archive half paleomagnetic data } \\
\text { collected during IODP Expedition 330 } \\
\square \\
\text { Lava flows identified with an ISCI = 3 } \\
\text { and 2 score }\end{array}$
\end{tabular}
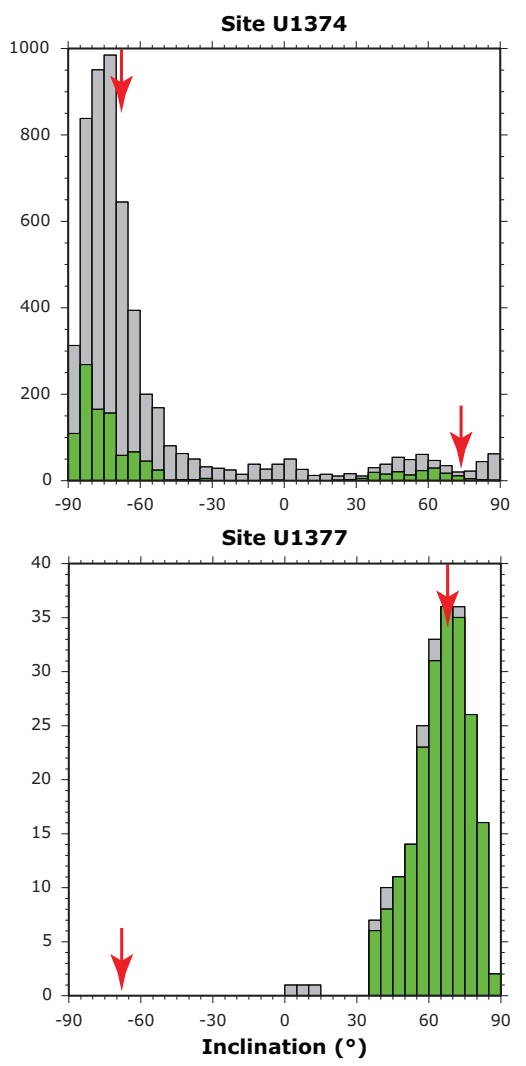

Figure 8. Compilation of inclination histograms for measured 2-cm archive half data. All situ lava flow units are indicated in green. We note that the gray histograms include lava flow and volcaniclastic/sedimentary units. Total numbers of observations are listed in the table in the top right corner, whereas the red arrows indicate the present-day inclination value for the Louisville hotspot at $51^{\circ}-52^{\circ} \mathrm{S}$ latitude. Figure after Koppers et al. (2012b). tiation in the Louisville seamounts. Both minerals are frequently observed as phenocrysts (Fig. 4) in the recovered lavas and are often well preserved (Koppers et al., 2012a). The high abundance of olivine phenocrysts in particular will allow post-cruise He (and Os) isotopic studies to further characterize the mantle source of the Louisville plume. Since no He isotopes have been previously published from Louisville, these studies will help to evaluate whether Louisville indeed represents a primary (deep?) hotspot (Courtillot et al., 2003). In addition, the composition of olivine phenocrysts (from less evolved samples) can be used to determine the $\mathrm{Mg} / \mathrm{Fe}$ ratio of the parental magma, which is indicative of the potential temperature of the Louisville mantle plume source (Putirka et al., 2007). 


\section{Geomicrobiology of Seamounts}

During Exp. 330 a large collection of igneous basement samples was devoted to microbiology studies to provide an excellent opportunity for studying living and extant microbial residents in old subseafloor volcanic rocks that make up the Louisville seamounts. Whole-round samples (5-20 cm long) were collected for microbiological analysis before the core sections were split into working and archive halves. Lithologies of the collected samples ranged from unconsolidated sediments to sedimentary conglomerates, volcaniclastics, volcanic breccias, and various kinds of basaltic lava flows and dike intrusions. All samples were preserved for shore-based cell counting, DNA analyses, and $\delta^{34} \mathrm{~S}$ and $\delta^{13} \mathrm{C}$ isotope analyses. Some samples were used to inoculate culturing experiments with different types of cultivation media, and during shipboard analytical work microbial growth was detected in samples as deep as 400 mbsf in Rigil Guyot, particularly with media targeting sulfur-oxidizing bacteria and general heterotrophs. Other samples were prepared to set up stable isotope addition bioassays to determine rates of carbon and nitrogen utilization by subsurface microbes.

These studies are of great interest as differences in microbial populations between overlying (pelagic) sediments and volcaniclastic layers and the basaltic basement are so far largely unidentified, as are the largely unstudied variations between different seamount lithologies, depth into the seamount, and seamounts of different age. Because of the high number of fresh volcanic glass occurrences at most Exp. 330 drill sites, the search for and study of microbial fossil traces will provide new information on the activity of and boring patterns generated by glass-metabolizing microorganisms in the largely unstudied seamount subsurface environment.

\section{Conclusions and Future Work}

IODP Exp. 330 to the Louisville seamount trail most successfully cored $1114 \mathrm{~m}$ of sediment and igneous basement with an average $72.4 \%$ recovery at five seamounts. The cored materials are relatively unaltered, providing an affluence of well-preserved basaltic samples that contain, for example, pristine olivine crystals and fresh volcanic glass. The high recovery and superior sample conditions allowed us to carry out large numbers of shipboard paleomagnetic analyses on in situ lava flows that in turn provided direct evidence for a limited latitudinal motion of the Louisville hotspot between $70 \mathrm{Ma}$ and $50 \mathrm{Ma}$ (Koppers et al., 2012b). However, it is important to emphasize that at all drill sites large fractions of mostly submarine hyaloclastites, volcanic sandstone, and basaltic breccia were recovered, which makes estimating the paleolatitude for the Louisville hotspot more difficult than for the sites in the Hawaiian-Emperor seamount trail, where sequences of primarily subaerial lava flows were re-covered (Duncan et al., 2006). As shown in this paper, many of these volcaniclastic units in the Louisville seamounts have inclinations consistent with bracketing lava flows. Deciphering the origin and timing of the remanence acquisition in these volcaniclastic units will play a critical role in resolving the paleolatitude history for the Louisville hotspot. Following the shipboard inclination measurements and initial radiometric age dating, this will require additional ${ }^{40} \mathrm{Ar} /{ }^{39} \mathrm{Ar}$ age determinations, paleomagnetic and rock magnetic studies, and integration of additional shore-based and shipboard data (e.g., borehole magnetic anomalies).

Ultimately, the results of Exp. 330 provide a next step in testing the "fixed" hotspot hypothesis and to better understanding the large-scale mantle movements that occur over long geological intervals on Earth. Many questions still remain to be answered, and they will require future seamount drilling to establish paleolatitude histories for other long-lived hotspot systems (for example, the Walvis Ridge), located in the SE Atlantic. Such broader data sets will allow us to address the possibility of "true polar wander" (Besse, et al., 2002, and Torsvik, et al., 2002) that still is an often controversial but also largely untested science hypothesis.

\section{The IODP Expedition 330 Scientific Party}

Louise Anderson, Christoph Beier, David M. Buchs, Li-Hui Chen, Benjamin E. Cohen, Fabien Deschamps, Michael J. Dorais, Daniel Ebuna, Sebastian Ehmann, J. Godfrey Fitton, Patrick M. Fulton, Erdenesaikhan Ganbat, Jeffrey S. Gee, Cedric Hamelin, Takeshi Hanyu, Hiroyuki Hoshi, Lara Kalnins, Johnathon Kell, Shiki Machida, John J. Mahoney, Kazuyoshi Moriya, Alexander R.L. Nichols, Nicola Pressling, Svenja Rausch, Shin-ichi Sano, Jason B. Sylvan, and Rebecca Williams.

\section{Acknowledgments}

This research used samples and data provided by IODP. The JOIDES Resolution captain, crew and technicians are thanked for their support during IODP Expedition 330. Patty Keizer is thanked for preparing the illustrations for this manuscript.

\section{References}

Bas, M. J. L., Maitre, R. W. L., Streckeisen, A., and Zanettin, B., 1986. A chemical classification of volcanic rocks based on the total alkali-silica diagram. J. Petrol., 27(3):745-750. doi:10.1093/petrology/27.3.745

Beier, C., Vanderkluysen, L., Regelous, M., Mahoney, J. J., and Garbe-Schönberg, D., 2011. Lithospheric control on geochemical composition along the Louisville Seamount Chain. Geochem. Geophys. Geosyst., 12(9):Q0AM01. doi:10.1029/ 2011GC003690

Besse, J., and Courtillot, V. (2002) Apparent and true polar wander and the geometry of the geomagnetic field over the $200 \mathrm{Myr}$. J. Geophys. Res., 107, 2300, dpi:10.1029/2001JB000050. 
Chen, C.- Y., and Frey, F. A., 1985. Trace element and isotope geochemistry of lavas from Haleakala Volcano, East Maui: Implications for the origin of Hawaiian basalts. J. Geophys. Res., 90(B10):8743-8768. doi:10.1029/JB090iB10p08743

Cheng, Q., Park, K. H., Macdougall, J. D., Zindler, A., Lugmair, G. W., Staudigel, H., Hawkins, J., and Lonsdale, P., 1987. Isotopic evidence for a hot spot origin of the Louisville Seamount Chain. In Keating, B. H., Fryer, P., Batiza, R., and Boehlert, G. W. (Eds.), Seamounts, Islands, and Atolls, Geophys. Monogr. Ser., 43:283-296. doi:10.1029/GM043p0283

Courtillot, V., Davaille, A., Besse, J., and Stock, J., 2003. Three distinct types of hotspots in the Earth's mantle. Earth Planet. Sci. Lett., 205(3-4):295-308. doi:10.1016/S0012-821X (02) 01048-8

Cowen, J. P., Giovannoni, S. J., Kenig, F., Johnson, H. P., Butterfield, D., Rappé, M. S., Hutnak, M., and Lam, P., 2003. Fluids from aging ocean crust that support microbial life. Science, 299(5603):120-123. doi:10.1126/science. 1075653

Downey, N. J., Stock, J. M., Clayton, R. W., and Cande, S. C., 2007. History of the Cretaceous Osbourn spreading center. $J$. Geophys. Res, 112(B4):B04102. doi:10.1029/2006JB004550

Duncan, R. A., and Clague, D. A., 1985. Pacific plate motion recorded by linear volcanic chains. In Nairn, A. E. A., Stehli, F. L., and Uyeda, S. (Eds.), The Ocean Basins and Margins: New York (Plenum Press), 89-121. doi:10.1007/978-1-4613-2351-8_3

Duncan, R. A., Tarduno, J. A., and Scholl, D. W., 2006. Leg 197 synthesis: Southward motion and geochemical variability of the Hawaiian Hotspot. In Duncan, R. A., Tarduno, J. A., Davies, T. A., and Scholl, D. W., Proc. ODP, Sci. Results, 197: College Station, TX (Ocean Drilling Program). doi:10.2973/odp. proc.sr.197.001.2006

Expedition 330 Scientists, 2011. Louisville Seamount Trail: Implications for geodynamic mantle flow models and the geochemical evolution of primary hotspots. IODP Prel. Rept., 330. doi:10.2204/iodp.pr.330.2011

Fisk, M. R., Giovannoni, S. J., and Thorseth, I., 1998. Alteration of oceanic volcanic glass: Textural evidence of microbial activity. Science, 281(5379):978-980. doi:10.1126/science. 281.5379 .978

Geldmacher, J., Hoernle, K., Klügel., A., Bogaard, P.v.d., and Bernin, B., 2006. Origin and geochemical evolution of the MadeiraTore Rise (eastern North Atlantic). J. Geophys. Res., 111(B9):B09206. doi:10.1029/2005JB003931

Hawkins, J. W., Lonsdale, P. F., and Batiza, R., 1987. Petrologic evolution of the Louisville seamount chain. In Keating, B. H., Fryer, P., Batiza, R., and Boehlert, G. W. (Eds.), Seamounts, Islands, and Atolls. Geophys. Monogr., 43:235-254.

Kono, M., 1980. Paleomagnetism of DSDP Leg 55 basalts and implications for the tectonics of the Pacific Plate. In Shambach, J., Jackson, E. D., Koizumi, I., Avdeiko, G., Butt, A., Clague, D., Dalrymple, G. B., et al., Init. Repts. DSDP, 96: Washington, DC (U.S. Govt. Printing Office), 737-752.

Koppers, A. A. P., Duncan, R. A., and Steinberger, B., 2004. Implications of a non-linear ${ }^{40} \mathrm{Ar} /{ }^{39} \mathrm{Ar}$ age progression along the Louisville seamount trail for models of fixed and moving hotspots. Geochem. Geophys. Geosyst., 5(6):Q06L02. doi:10.1029/2003GC000671
Koppers, A. A. P., Gowen, M. D., Colwell, L. E., Gee, J. S., Lonsdale, P. F., Mahoney, J. J., and Duncan, R. A., 2011. New ${ }^{40} \mathrm{Ar} /{ }^{39} \mathrm{Ar}$ age progression for the Louisville hot spot trail and implications for inter-hot spot motion. Geochem. Geophys. Geosyst., 12(12):Q0AM02. doi:10.1029/2011GC003804

Koppers, A. A. P., Morgan, J. P., Morgan, J. W., and Staudigel, H., 2001. Testing the fixed hotspot hypothesis using ${ }^{40} \mathrm{Ar} /{ }^{39} \mathrm{Ar}$ age progressions along seamount trails. Earth Planet. Sci. Lett., 185(3-4):237-252. doi:10.1016/S0012-821X(00) 00387-3

Koppers, A. A. P., Yamazaki, T., and Geldmacher, J., 2010. Louisville Seamount Trail: Implications for geodynamic mantle flow models and the geochemical evolution of primary hotspots. IODP Sci. Prosp., 330. doi:10.2204/iodp.sp.330.2010

Koppers, A. A. P., Yamazaki, T., Geldmacher, J., and the Expedition 330 Scientists, 2012a. Proc. IODP, 330: Washington, DC (Integrated Ocean Drilling Program Management International, Inc.). doi:10.2204/iodp.proc.330.2012

Koppers, A. A. P., Yamazaki, T., Geldmacher, J., Gee, J. S., Pressiling, N., Hoshi, H., Anderson, L., et al., 2012b. Limited latitudinal mantle plume motion for the Louisville hotspot. Nature Geosci., 5:911-917. doi:10.1038/ngeo1638

Lonsdale, P., 1988. Geography and history of the Louisville Hotspot Chain in the southwest Pacific. J. Geophys. Res., 93(B4):3078-3104. doi:10.1029/JB093iB04p03078

Macdonald, G. A., and Katsura, T., 1964. Chemical composition of Hawaiian lavas. J. Petrol., 5(1):82-133. doi:10.1093/ petrology/5.1.82

Mason, O. U., Nakagawa, T., Rosner, M., Van Nostrand, J. D., Zhou, J., Maruyama, A., Fisk, M. R., and Giovannoni, S. J., 2010. First investigation of the microbiology of the deepest layer of ocean crust. PLoS ONE, 5(11):e15399. doi:10.1371/journal. pone.0015399

Morgan, W. J., 1971. Convection plumes in the lower mantle. Nature, 230(5288):42-43. doi:10.1038/230042a0

Mortimer, N., Hoernle, K., Hauff, F., Palin, J. M., Dunlap, W. J., Werner, R., and Faure, K., 2006. New constraints on the age and evolution of the Wishbone Ridge, southwest Pacific Cretaceous microplates, and Zealandia-West Antarctica breakup. Geology, 34(3):185-188. doi:10.1130/G22168.1

Parkes, R. J., Cragg, B. A., Bale, S. J., Getlifff, J. M., Goodman, K., Rochelle, P. A., Fry, J. C., Weightman, A. J., and Harvey, S. M., 1994. Deep bacterial biosphere in Pacific Ocean sediments. Nature, 371(6496):410-413. doi:10.1038/371410a0

Phipps Morgan, J., 1999. Isotope topology of individual hotspot basalt arrays: Mixing curves or melt extraction trajectories? Geochem. Geophys. Geosyst., 1:1003. doi:10.1029/1999 GC000004

Putirka, K. D., Perfit, M., Ryerson, F. J., and Jackson, M. G., 2007. Ambient and excess mantle temperatures, olivine thermometry, and active vs. passive upwelling. Chemical Geology, 241(3-4):177-206. doi:10.1016/j.chemgeo.2007.01.014

Rouxel, O., Ono, S., Alt, J., Rumble, D., and Ludden, J., 2008. Sulfur isotope evidence for microbial sulfate reduction in altered oceanic basalts at ODP Site 801. Earth Planet. Sci. Lett., 268(1-2):110-123. doi:10.1016/j.eps1.2008.01.010

Steinberger, B., and Antretter, M., 2006. Conduit diameter and buoy- 
ant rising speed of mantle plumes: Implications for the motion of hot spots and shape of plume conduits. Geochem. Geophys. Geosyst., 7(11):Q11018. doi:10.1029/2006GC001409 Steinberger, B., and Calderwood, A.R., 2006. Models of large-scale viscous flow in the Earth's mantle with constraints from mineral physics and surface observations. Geophys. J. Int., 167(3):1461-1481. doi:10.1111/j.1365-246X.2006.03131.x

Steinberger, B., and O'Connell, R. J., 1998. Advection of plumes in mantle flow: Implications for hotspot motion, mantle viscosity and plume distribution. Geophys. J. Int., 132(2):412-434. doi:10.1046/j.1365-246x.1998.00447.x

Steinberger, B., Sutherland, R., and O'Connell, R. J., 2004. Prediction of Emperor-Hawaii seamount locations from a revised model of global plate motion and mantle flow. Nature, 430(6996):167-173. doi:10.1038/nature02660

Tarduno, J., Bunge, H.- P., Sleep, N., and Hansen, U., 2009. The bent Hawaiian-Emperor hotspot track: Inheriting the mantle wind. Science, 324(5923):50-53. doi:10.1126/science. 1161256

Tarduno, J. A., 2007. On the motion of Hawaii and other mantle plumes. Chem. Geol., 241(3-4):234-247. doi:10.1016/j. chemgeo.2007.01.021

Tarduno, J. A., and Cottrell, R. D., 1997. Paleomagnetic evidence for motion of the Hawaiian hotspot during formation of the Emperor seamounts. Earth Planet. Sci. Lett., 153(3-4):171180. doi:10.1016/S0012-821X(97)00169-6

Tarduno, J.A., Duncan, R. A., Scholl, D. W., Cottrell, R. D., Steinberger, B., Thordarson, T., Kerr, B. C., et al., 2003. The Emperor seamounts: Southward motion of the Hawaiian hotspot plume in Earth's mantle. Science, 301(5636):1064-1069. doi:10.1126/science.1086442

Torsvik, T.H., Van der Voo, R., and Redfield, T.F. (2002) Relative hotspot motions versus True Polar Wander. Earth Planet. Sci. Lett., 202, 185-200.

Vanderkluysen, L., Mahoney, J., Koppers, A. A. P., and Lonsdale, P. F., 2007. Geochemical evolution of the Louisville seamount chain. EOS Trans. AGU, 88(52, Fall Meet. Suppl.): V42B-06.

Watts, A. B., Weissel, J. K., Duncan, R. A., and Larson, R. L., 1988. Origin of the Louisville Ridge and its relationship to the Eltanin Fracture Zone system.J. Geophys. Res., 93(B4):30513077. doi:10.1029/JB093iB04p03051

Wessel, P., and Kroenke, L. W., 2008. Pacific absolute plate motion since $145 \mathrm{Ma}$ : An assessment of the fixed hot spot hypothesis. J. Geophys. Res., 113(B6):B06101. doi:10.1029/ 2007JB005499

Wessel, P., Harada, Y., and Kroenke, L., 2006. Toward a self-consistent, high-resolution absolute plate motion model for the Pacific. Geochem. Geophys. Geosyst., 7(3):Q03L12. doi:10.1029/ 2005GC001000

Wilson, J. T., 1963. A possible origin of the Hawaiian Islands. Canad. J. Phys., 41(6):863-870. doi:10.1139/p63-094

Worthington, T. J., Hekinian, R., Stoffers, P., Kuhn, T., and Hauff, F., 2006. Osbourn Trough: Structure, geochemistry and implications of a mid-Cretaceous paleospreading ridge in the South Pacific. Earth Planet. Sci. Lett., 245(3-4):685-701. doi:10.1016/j.epsl.2006.03.018

\section{Authors}

Anthony A.P. Koppers, College of Oceanic \& Atmospheric Sciences, Oregon State University, 104 CEOAS Administration Building, Corvallis, OR 97331-5503, U.S.A., e-mail:akoppers@coas.oregonstate.edu

Toshitsugu Yamazaki, (Currently) Atmosphere and Ocean Research Institute, University of Tokyo, 5-1-5 Kashiwanoha, Kashiwa, Chiba 277-8564, Japan

Jörg Geldmacher, (Currently) GEOMAR, Helmholtz Centre for Ocean Research Kiel, 24148 Kiel, Germany and the IODP Expedition 330 Scientific Party 